\title{
APPLICATION OF THE MULTIFRACTIONAL BROWNIAN MOTION PROCESS IN SPATIAL ANALYSES
}

\begin{abstract}
The article combines methodology applied for time series with elements of spatial econometrics. Its aim is to present a modified method of spatial modelling using selected stochastic processes and the application of that method in economics and other fields of science. The research hypothesis verified in this work can be described as follows: generalised to a multivariate case, Brownian motion processes are a useful tool in econometrics modelling as well as in the analysis of variability and correlation in space. The multifractional Brownian motion process is applied to conduct an analysis of the degree and variability of environmental pollution. The article comprises an introduction, a theoretical part in which concepts connected with the class of stochastic processes in question are clarified, and an empirical part, where selected applications of the aforementioned method are discussed.
\end{abstract}

Keywords: stochastic process, Hölder function, spatial modelling, variability analysis. JEL Classification: C15, C32, C33, C51.

\section{Introduction}

Phenomena and processes that are the subject of studies in economics, environmental science and epidemiology take place in specified spatial-temporal conditions. Analysing these processes, we notice the influence of space and time on their course.

This article describes two types of modelling approach. Both a methodology of time series including Brownian motion processes, and

Adrianna Mastalerz-Kodzis, University of Economics in Katowice, Faculty of Management, Department of Statistics, Econometrics and Mathematics, 1 Maja 50, 40-287 Katowice, Poland, e-mail: adrianna.mastalerz-kodzis@ue.katowice.pl 
elements of spatial econometrics, in particular methods of new economic geography - are applied. Special attention is paid to processes with a so-called long memory. As early as 1952, T. Hagerstrand pointed to the existence of the memory effect in the spread of economic phenomena, while P. R. Krugman (1991) introduced the development of quantitative methods in spatial analyses. The generalised multifractional Brownian motion process is applied in the present work in the modelling of the variability of spatial data and in the study of spatial correlation. Pointwise Hölder exponents are used in the analysis of variability in space (Ayache \& Lévy Véhel 1999, Mastalerz-Kodzis 2003). Selected elements of statistics and spatial econometrics are applied (Paelinck \& Klaassen 1983, Suchecki 2010). Methods from time series analysis are implemented in the modelling of data in space and are generalised to a multivariate case (Lévy Véhel \& Mendivil 2011, Falconer \& Lévy-Véhel 2008, Ayache \& Taqqu 2004, Barrière 2007, Echelard, Lévy Véhel and Barrière 2010).

Theoretical considerations connected with the presented topic were focused on, among others, the following works: Mastalerz-Kodzis (2003), Mastalerz-Kodzis (2016b), and Mastalerz-Kodzis and Pośpiech (2017). The aim of the article is to present a modified method of spatial modelling using selected stochastic processes and the application of that method in economics and other fields of science. The research hypothesis verified in this work can be described as follows: generalised to a multivariate case, Brownian motion processes are a useful tool in econometrics modelling as well as in the analysis of variability and correlation in space. The article is composed of two parts: theoretical and empirical.

\section{Random Fields}

When analysing phenomena and processes that are the subject of studies in economics, environmental science and epidemiology, we notice the influence of space and time on their course and form. Moreover, in almost all cases, the changes taking place are of a random character. Therefore, we must study them in the categories of random fields.

Let $Y_{i}, i=1, \ldots, k$ be a variable which undergoes random fluctuations in space, then $Y=\left[\begin{array}{llll}Y_{1} & \ldots & Y_{k}\end{array}\right]^{T} k-$ a dimensional random field, e.g. a function of the form $Y: D \times \Omega \rightarrow R^{k}, D \subset R^{3}$, such that for each $x_{0} \in D$ the value $Y\left(x_{0}, \omega\right)$ is a $k$-dimensional random vector determined on a set probabilistic space $(\Omega, A, P)$, whereby $R^{3}=\left\{\left(x_{1}, x_{2}, t\right)\right\}$, while $x_{1}, x_{2}$ stand for longitude and latitude, and $t$ stands for the time variable. 
Each of the components of vector $Y$ is a random field, e.g. the function $Y_{i}: D \times \Omega \rightarrow R^{1}, i=1, \ldots, k$, such that for each $x_{0} \in D$ value $Y_{i}\left(x_{0}, \omega\right)$ is a random variable. If we determine a third time variable, then the random field $Y(x, \omega)$ is a static field and describes the course of an economic phenomenon in space; if, on the other hand, the variable undergoes fluctuations in time, then the random field also describes the dynamics of the examined phenomenon.

We can distinguish the following classes of random fields:

- homogeneous - invariable in regard to translation in $R^{3}$, e.g. $m\left(x+t_{0}\right)=m(x)$ (expected constant value) and $C\left(x_{1}+t_{0}, x_{2}+t_{0}\right)=C\left(x_{1}, x_{2}\right)$ - the covariance function for any $\left(x_{1}, x_{2}, t_{0}\right) \in R^{3}$,

- isotropic, for which the function of medium value and the correlation function are invariable in regard to rotations in $R^{3}$ (correlation depends on the distance between points).

We can prove that the multifractional Brownian motion is an isotropic, inhomogeneous random field, and that $E(Y(x, \omega))=0$ and $C(x, y)=\frac{1}{2}(|x|+|y|-|x-y|)$.

We agree on the following symbols: $Y(\cdot)$ - the level of the examined spatial-temporal phenomenon, $X(\cdot)$ - factors determining the phenomenon level, $u(\cdot)$ - a random field. Then: $f(Y(\cdot), X(\cdot) u(\cdot))=0$. The defined values depend on the spatial argument (of the point in the Euclidean space).

\section{Modelling of Time Series with the Use of Stochastic Processes}

\subsection{General Remarks}

The multifractional Brownian motion process (dependent on time) can be used in the modelling of time series. The process with stationary increments, which feature fractional parts of Brownian motion, depends on a constant parameter - the Hurst exponent. This exponent belongs to the range $(0,1)$ and divides the time series into: persistent - with a positive correlation between the subsequent implementations $(H \in(1 / 2,1))$, and anti-persistent, in which the correlation is negative $(H \in(0,1 / 2))$. A general case is considered below - processes dependent on the Hölder function. Fractional processes are an exceptional example of multifractional ones, that is, the constant Hölder function is the value of the Hurst exponent. 


\subsection{Pointwise Hölder Exponent}

Let there be a function $f: D \rightarrow \Re(D \subset \Re)$ and a parameter $\alpha \in(0,1)$. Function $f$ is a Hölder function of class $C^{\alpha}$, if there are constants $c>0$ and $h_{0}>0$ such that for each $x$ as well as all of $h$ such that $0<h \leq h_{0}$ the following inequality is fulfilled (Daoudi, Lévy Véhe \& Meyer 1998, Mastalerz-Kodzis 2003):

$$
|f(x+h)-f(x)| \leq c h^{\alpha} .
$$

The Hölder function is of class $C^{\alpha}$ in the surrounding of any point from the domain. As parameter $\alpha \in(0,1)$, we can consider fractional differentiation. The Hölder function is by definition a continuous function in the range. If the function is of class $C^{l}$, then the fractional value of the function graph equals one. When we only assume that the function is of class $C^{0}$, then the graph can feature a fractional measure. When we interpret the value of the derivative, then the speed of value variation at the change of the argument is determined. Therefore, when time is the argument (or geographical coordinates of location), then the value of the derivative is the speed of the variation in time (or variation resulting from location on a plane).

Let $x_{0} \in D \subset \Re$. Function $f: D \rightarrow \Re$ is at point $x_{0}$ a Hölder function of class $C_{x_{0}}^{\alpha}$, if there are constants $\varepsilon, c>0$ such that for each $x \in\left(x_{0}-\varepsilon, x_{0}+\varepsilon\right)$ the following inequality is fulfilled:

$$
\left|f(x)-f\left(x_{0}\right)\right| \leq c\left|x-x_{0}\right|^{\alpha} .
$$

The Hölder point exponent of function $f$ at point $x_{0}$ is the number $\alpha_{f}\left(x_{0}\right)$ expressed by the formula $\alpha_{f}\left(x_{0}\right)=\sup \left\{\alpha: f \in C_{x_{0}}^{\alpha}\right\}$. The Hölder function for function $f$ is the function which to each of the points $x \in D$ assigns the number $\alpha_{f}(x)$.

\subsection{Multifractional Brownian Process}

Let $H_{t}:[0, \infty) \rightarrow(0,1)$ be a Hölder function with an exponent $a>0$. A multi-fractional Brownian motion process with function parameter $H_{t}$ is a stochastic process $B_{H_{t}}(t)$ defined for $t \geq 0$ by the formula (Ayache \& Lévy Véhel 1999, Peltier \& Lévy Véhel 1995, Mastalerz-Kodzis 2003):

$$
B_{H t}(t)=\frac{1}{\Gamma\left(H_{t}+\frac{1}{2}\right)}\left\{\int_{-\infty}^{0}\left[(t-s)^{H_{t}-1 / 2}-(-s)^{H_{t}-1 / 2}\right] d B(s)+\int_{0}^{t}(t-s)^{H_{t}-1 / 2} d B(s)\right\},
$$

where $B$ is the standard Brownian motion process. 
The Hölder point exponents inform about the characteristics of the process. Among others, we note that the process does not feature stationary increments when the Hölder function is not constant, and the closer the values of the function are to zero, the bigger the variability of the graph; for function values close to one, the process is smoother. The regularity of the process measured with Hölder point exponents changes in the range $(0,1)$.

In the multifractional Brownian motion process, the Hölder function is a constant function, which means that the regularity of the process trajectory measured by this function also changes continuously. Further generalisation of the Brownian motion process is based on the replacement of the continuous Hölder function with an discontinuous one (Peltier \& Lévy Véhel 1995). A generalised multifractional Brownian motion process, with function parameter $H(t)$ and $\lambda$ - a real number, is process $\left\{B_{H, \lambda}(t)\right\}_{t \in \Re}$ such that for each $t \in \mathfrak{R}$ :

$$
B_{H, \lambda}(t)=\sum_{n=0}^{\infty} \int_{D_{n}} \frac{e^{i t \xi}-1}{|\xi|^{H_{n}(t)+0,5}} d B(\xi),
$$

where $D_{0}=\{\xi:|\xi|<1\}$ and for all $n \geq 1 D_{n}=\left\{\xi: \lambda^{n-1} \leq|\xi|<\lambda^{n}\right\}$.

The multifractional Brownian motion process can be generated with the use of random relocation of the segment midpoint method (Mastalerz-Kodzis 2003, Mastalerz-Kodzis 2016a). Values of the Hölder function close to zero imply a bigger variability of the process; the closer the exponents are to 1 , the smaller the variability.
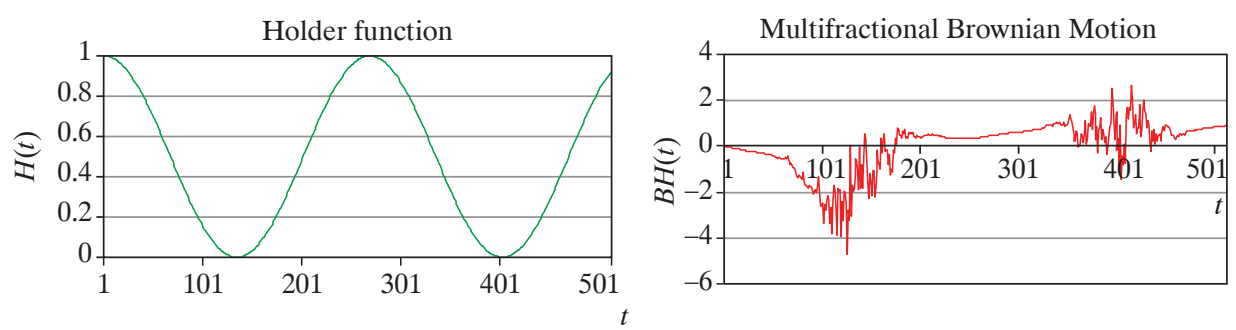

Fig. 1. Multifractional Brownian Motion Process: Hölder Function in the Form $H(t)=\cos ^{2}(6 t)$ and Process Simulation for the Set Function $H(t)$

Source: author's own study (formula (5)).

Generally, also in this stage the value of the process is set by the formula:

$$
B_{H(t)}(t)=\frac{B(t-d)+B(t+d)}{2}+G \frac{\sqrt{1-2^{2 H(t)-2}}}{2^{i^{*} H(t)}},
$$


where $t-d$ and $t+d$ are the former points of time segment interval $(0,1)$ (see Figure 1).

According to the formula included in Peltier and Levy Vehel (1995) and Mastalerz-Kodzis (2003), we can also estimate pointwise Hölder exponents. Let us use the symbol $\left\{B_{i, n}=B_{H}\left(\frac{i}{n}\right), 0 \leq i \leq n\right\}$ to indicate a Brownian motion process with the Hurst exponent H. Let $S_{n}$ be given by the formula $S_{n}=\frac{1}{n-1} \sum_{i=1}^{n-1}\left|B_{i+1, n}-B_{i, n}\right|$ and $H_{n}=-\frac{\log \left(\sqrt{\pi / 2} S_{n}\right)}{\log (n-1)}$. Then $\lim _{n \rightarrow \infty} H_{n}=H$.

Let $1<k<n$ be the length of the neighbourhood (range) used to estimate function $\mathrm{H}$. We are going to estimate a function for $t$ from the range $(k / n, 1-(k / n))$. Then the estimator $\hat{H}(i /(n-1))$ for $S_{k, n}(i)=\frac{m}{n-1} \sum_{j=i-k / 2}^{i+k / 2}\left|B_{j+1, n}-B_{j, n}\right|$ is
as follows:

$$
\hat{H}_{i /(n-1)}=-\frac{\log \left(\sqrt{\pi / 2} S_{k, n}(i)\right)}{\log (n-1)} .
$$

\section{Spatial Analyses with the Use of Hölder Function Properties}

New Economic Geography (NEG) is a field of science and economics that deals with spatial aspects, among others, with the localisation of economic activity in the world (Suchecki 2010). In the 21st century, consideration of, for instance, the effects of globalisation or environmental pollution is possible, among others, with the use of NEG methods. It is considered that space (geographical location, distance, neighbourhood) has a significant influence on the formation of a given phenomenon or economic process.

In this article, multifractional Brownian motions are, in spatial terms, a tool that enables us to conduct spatial analyses; a study of the variability of the examined phenomenon depending on location and time is conducted. Using the Hölder function we can describe e.g. the differentiation of environmental pollution levels.

The pointwise Hölder exponent is dependent only on parameter $t$ and is responsible for the variability of a process around any point in the range. However, taking into consideration the NEG approach, we can inquire about the application of methodology to spatial economic analyses, conditioning the analyses on specific points in space and taking into consideration the memory effect. 
According to the literature (Ayache \& Taqqu 2004, Barrière 2007, Echelard, Lévy Véhel and Barrière 2010, Falconer \& Lévy-Véhel 2008, Lévy Véhel \& Mendivil 2011), the application of methodology in NEG or, more broadly, in spatial econometrics, in analysis of spatial autocorrelation, and in the study of the temporal and spatial memory effect with the Hölder function is justified.

Therefore, generalising to a multivariate case, the Hölder function is dependent on time $t$ and also on a point on a plane $(x, y)$. Therefore, we obtain function $H_{t}(x, y)$ for $\alpha>0$ and process $B_{H_{t}(x, y), \lambda}(x, y, t)$.

Let $H$ be a continuous function. The two-dimensional multifractional Brownian motion process is a process with stationary or non-stationary increments with a covariance function expressed by the formula:

$$
E\left(B_{H(.)}(x), B_{H(.)}(y)\right)=\|x\|^{H(x)+H(y)}+\|y\|^{H(x)+H(y)}-\|x-y\|^{H(x)+H(y)} .
$$

The Hölder exponent measures the regularity of the function graph. If we assume that $H$ is a differentiable function, then, with probability 1 for each $(x, y)$, equality $\alpha_{B_{H(x, y)}}(x, y)=H(x, y)$ takes place. Works by Mastalerz-Kodzis (2016b) and Mastalerz-Kodzis and Pośpiech (2017) describe the way of generating spatial processes dependent on the Hölder function. The first iterative stage of generating the multifractional Brownian motion process in space can be expressed by the following formula:

$$
B_{H_{t}(x, y), \lambda}(x, y, t)=\frac{B_{t-1}\left(x_{1}, y_{1}\right)+B_{t-1}\left(x_{2}, y_{2}\right)}{2}+\frac{\sqrt{1-2^{2 H_{t}(x, y)-2}}}{2^{i * H_{t}(x, y)}},
$$

where $\left(x_{1}, y_{1}\right),\left(x_{2}, y_{2}\right)$ are the former division points, $H(x, y)$ is the value of the Hölder function for argument $(x, y)$, whereas $G$ in subsequent stages is a series of pseudorandom numbers that constitute the implementation of a variable with a normal distribution $N(0,1)$.

\section{Application of the Pointwise Hölder Exponent in Economic and Epidemiological Spatial Analyses and in Environmental Pollution Tests}

Multifractional Brownian motions in spatial terms can be used as a tool that allows multidirectional socio-economic studies to be conducted. Using the value of the Hölder function we can describe e.g. the level of environmental pollution and the effects of an explosion. We can prove that the aforementioned values, as well as other socio-economic characteristics, 
are characterised by memory, which means that historical observations (considerably distant or not so distant) influence current values.

We assume that a subset of two-dimensional space $D \in R^{2}$ and a range of time $T$ is given. We can consider the following cases:

- a fixed moment in time $t_{0} \in T$. We can construct a map of the process values in a given moment of time (scan for $\left.t_{0}\right)$;

- a fixed point $\left(x_{0}, y_{0}\right) \in R^{2}$ (e.g. geographical coordinates). In this case we consider a stochastic process with stationary or non-stationary increments dependent on $t$. We can use the methods for time series. In a given place $\left(x_{0}, y_{0}\right) \in R^{2}$ the process values are the values of any socio-economic characteristic. We analyse the variability of the characteristic in time in a two-dimensional chart and study the memory of the series. For example, in the surrounding area of a given point on a plane we analyse population density, the intensity of occurrence of a certain disease unit, etc. (Mastalerz-Kodzis 2016a, Mastalerz-Kodzis \& Pośpiech 2017);

- on a continuous basis in the whole area of the analyses, changes in time and space can be illustrated in a film, where at a steady pace the expansion of a given phenomenon takes place, whereas its intensity is expressed by the point values of Hölder exponents with consideration of the memory effect.

The article by Mastalerz-Kodzis and Pośpiech (2017) describes the application of the aforementioned methods to analyse the spread of environmental pollution resulting from an explosion (in a strictly defined place on a plane with a consideration of time). The article suggests a computer simulation to measure the intensity of the spread of disease. In analyses of an economic nature, the effects of globalisation as well as spatial distribution, correlation, and the variability of characteristics are all described in the following works: Mastalerz-Kodzis (2016b), Mastalerz-Kodzis and Pośpiech (2017).

\section{Analysis of the Spatial Variability of Sulphur Dioxide $\left(\mathrm{SO}_{2}\right)$ Concentration in the Air in the Silesia Region}

Environmental pollution, and especially air pollution, is a serious problem in many cities in Poland as well as around the world. The effects of pollution have an impact on the lives and health of people. Various substances, many of which affect people's health very negatively, are present in the air. One of them is sulphur dioxide.

Sulphur dioxide $\left(\mathrm{SO}_{2}\right)$ is a colourless gas with a sharp, pungent and suffocating smell that severely irritates the respiratory tract. It is absorbed into 
the human organism by nasal mucosa and the upper part of the respiratory tract. It is poisonous for animals and harmful for plants. Sulphur dioxide is formed as a result fossil fuels that contain sulphur being burned in industrial works, municipal heating plants, and individual boilers. $\mathrm{SO}_{2}$ is responsible for smog in big urban agglomerations. The acceptable level of hourly sulphur dioxide concentration is $350 \mu \mathrm{g} / \mathrm{m}^{3}$, and it may be exceeded not more than 24 times a year. The acceptable level of average daily concentration is $125 \mu \mathrm{g} / \mathrm{m}^{3}$, and it may be exceeded not more than 3 times a year. An hourly sulphur dioxide concentration of $500 \mu \mathrm{g} / \mathrm{m}^{3}$ is considered alarming.

Empirical analysis was conducted on the basis of data for Poland for the years 2000-2015. The data originates from more than 8,000 measurements per year (24 times per day) carried out by 137 measuring stations in Poland (source: Chief Inspectorate of Environmental Protection (GIOS)). We present the results below, limiting them to one of the most polluted regions in Poland - the region of Silesia. The main results for 17 stations in the province of Silesia and for the station on Babia Góra are included in Table 1. We should note the huge number of measurements (more than 8,300 for each station), which confirms the very high level of completeness of the data (94.8-99.2\%). We clearly notice large differences between the minimum and maximum measurements. We can also see that the average concentration in the winter period is considerably higher than in the year as a whole.

Figure 2 presents selected average characteristics of environmental pollution due to $\mathrm{SO}_{2}$ in years 2000-2015 for a selected station in the province of Silesia, located nearest to the centre of the capital of Silesia Katowice. The time series indicate the decreasing average values of pollution indicators.

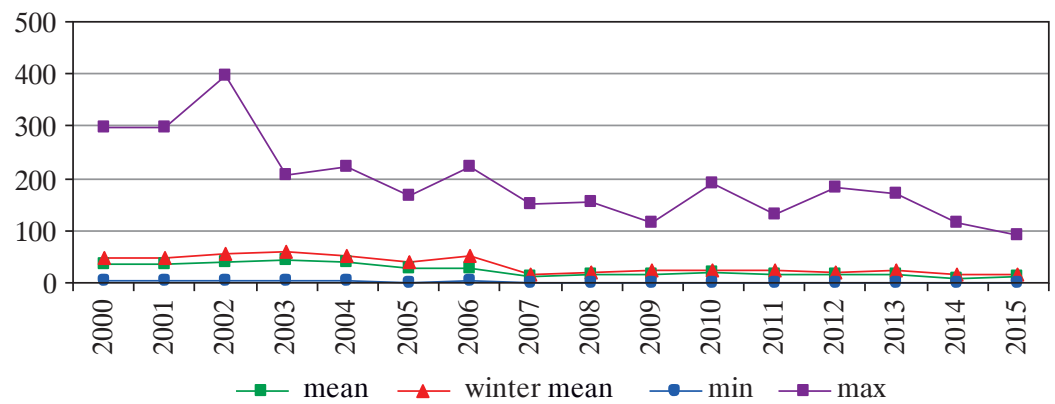

Fig. 2. Data on $\mathrm{SO}_{2}$ Concentration at the SIKatoKossut Station, 2000-2015

Source: GIOS, www.powietrze.gios.gov.pl (accessed: 20 March 2017), and the author's own study. 


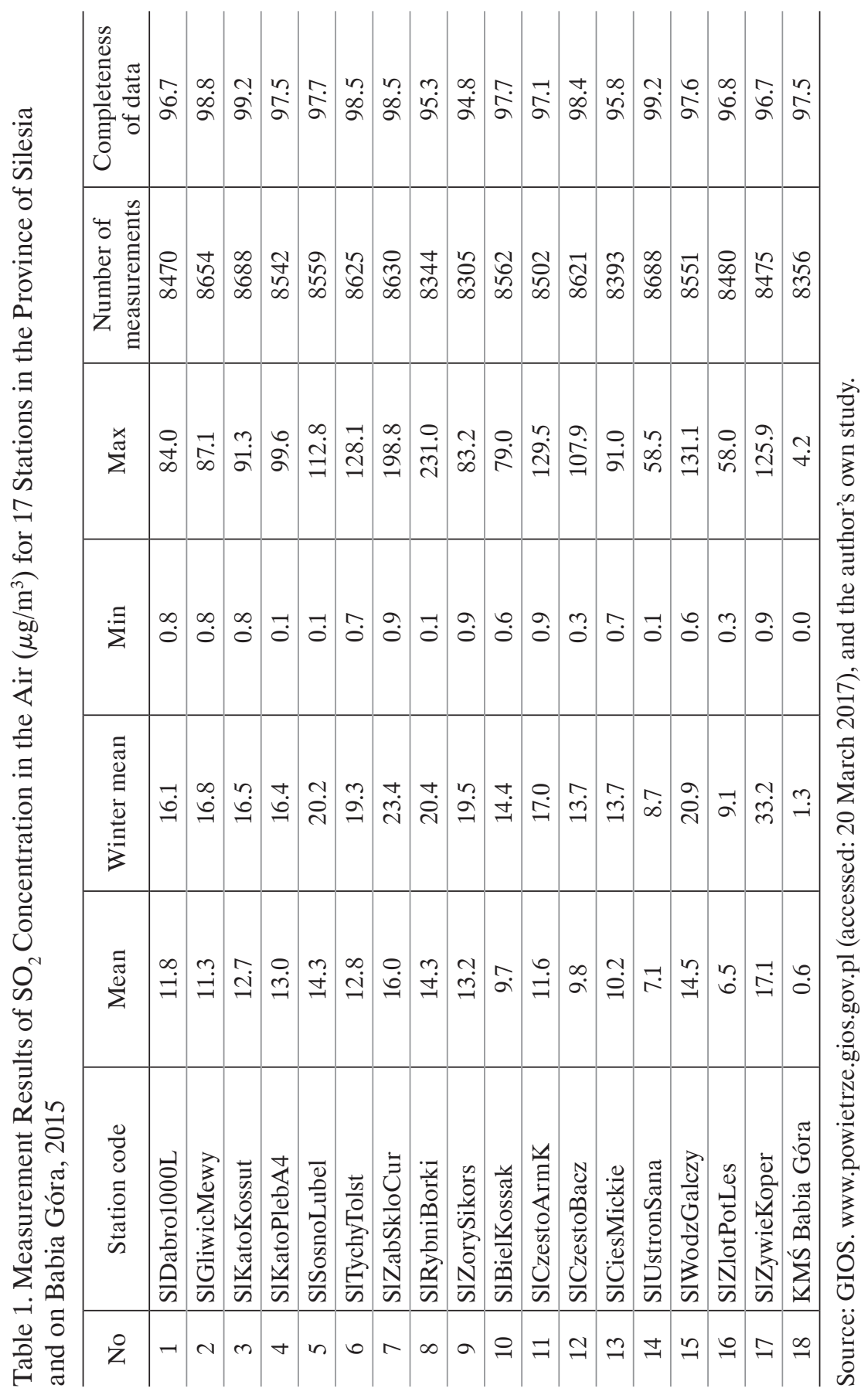


Figure 3 illustrates the data relating to the SIKatoKossut station. We present the measurements of $\mathrm{SO}_{2}$ concentration in 2015 and the estimated pointwise Hölder exponents. Using the methodology described in the theoretical part of the article as well as the conducted research, we can draw the following conclusions:

- we observe much bigger values of the exponents for the period from April to October. This means that the 24-hour variability of the $\mathrm{SO}_{2}$ pollution level is lower;

- lower values were recorded for the period from November to March. This suggests lower variability on the 24-hour pollution map and also positively correlates with a lower concentration of $\mathrm{SO}_{2}$ pollution (Table 1);

- higher fluctuations were recorded in November and December. We can assume that this is connected with differences in air temperature and the consequent need for heating;

- a high level of pollution was recorded in stations located near to large clusters of houses in the months when the air temperature was low.
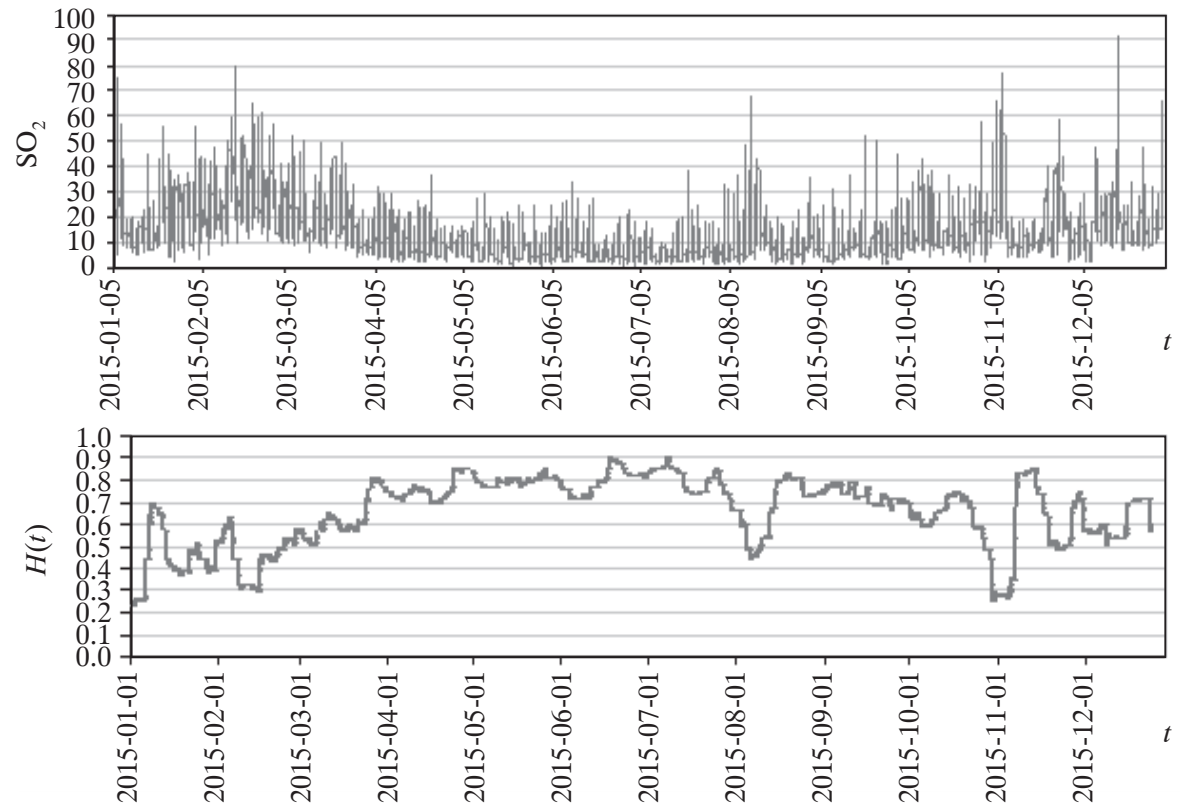

Fig. 3. Data on $\mathrm{SO}_{2}$ Concentration $\left(\mu \mathrm{g} / \mathrm{m}^{3}\right)$ at the SIKatoKossut Station, 2015. Estimated Pointwise Hölder Exponents

Source: GIOS, www.powietrze.gios.gov.pl (accessed: 20 March 2017), and the author's own calculations - estimation on the basis of formula (6). 
Further, using the geographical coordinates of the measuring stations, we defined a matrix of Euclidean distances between the stations. According to its values, we calculated the coefficients of correlation. The results are presented in Table 2.

We can state that:

- the described methodology allows to define coefficients of correlation between selected environmental pollution characteristics for specified points in space at a specified moment in time;

- there exists a strong positive relationship between environmental pollution caused by $\mathrm{SO}_{2}$ between measuring stations;

- the smaller the distance between stations, the stronger the relationship.

Table 2. Values of Correlation Coefficients with Consideration of the Memory Effect $(0.7<H(x, y, t)<0.76)$

\begin{tabular}{c|c|c|c|c|c|c|c|c|c|c|c|c|c|c|c|c|c|c}
\hline & 1 & 2 & 3 & 4 & 5 & 6 & 7 & 8 & 9 & 10 & 11 & 12 & 13 & 14 & 15 & 16 & 17 & 18 \\
\hline 1 & & & & & & & & & & & & & & & & & & \\
\hline 2 & 0.96 & & & & & & & & & & & & & & & & & \\
\hline 3 & 0.92 & 0.89 & & & & & & & & & & & & & & & & \\
\hline 4 & 0.85 & 0.83 & 0.81 & & & & & & & & & & & & & & & \\
\hline 5 & 0.76 & 0.74 & 0.73 & 0.69 & & & & & & & & & & & & & & \\
\hline 6 & 0.68 & 0.66 & 0.65 & 0.62 & 0.58 & & & & & & & & & & & & & \\
\hline 7 & 0.46 & 0.45 & 0.44 & 0.43 & 0.41 & 0.39 & & & & & & & & & & & & \\
\hline 8 & 0.41 & 0.40 & 0.39 & 0.38 & 0.36 & 0.35 & 0.31 & & & & & & & & & & & \\
\hline 9 & 0.99 & 0.95 & 0.92 & 0.85 & 0.76 & 0.67 & 0.46 & 0.41 & & & & & & & & & & \\
\hline 10 & 1.00 & 0.99 & 0.95 & 0.88 & 0.78 & 0.69 & 0.47 & 0.42 & 1.00 & & & & & & & & & \\
\hline 11 & 0.67 & 0.65 & 0.64 & 0.62 & 0.58 & 0.54 & 0.39 & 0.35 & 0.67 & 0.69 & & & & & & & & \\
\hline 12 & 0.79 & 0.77 & 0.76 & 0.72 & 0.66 & 0.60 & 0.42 & 0.37 & 0.79 & 0.82 & 0.59 & & & & & & & \\
\hline 13 & 0.92 & 0.89 & 0.86 & 0.80 & 0.72 & 0.64 & 0.44 & 0.39 & 0.91 & 0.95 & 0.64 & 0.75 & & & & & & \\
\hline 14 & 1.00 & 1.00 & 1.00 & 1.00 & 0.90 & 0.79 & 0.53 & 0.46 & 1.00 & 1.00 & 0.78 & 0.94 & 1.00 & & & & & \\
\hline 15 & 0.66 & 0.64 & 0.63 & 0.60 & 0.57 & 0.53 & 0.39 & 0.34 & 0.65 & 0.67 & 0.53 & 0.58 & 0.63 & 0.77 & & & & \\
\hline 16 & 1.00 & 1.00 & 1.00 & 1.00 & 0.91 & 0.80 & 0.53 & 0.47 & 1.00 & 1.00 & 0.80 & 0.96 & 1.00 & 1.00 & 0.78 & & & \\
\hline 17 & 0.69 & 0.35 & 0.24 & 0.43 & 0.33 & 0.25 & 0.31 & 0.32 & 0.21 & 0.20 & 0.24 & 0.15 & 0.06 & 0.13 & 0.06 & 0.51 & & \\
\hline 18 & 0.48 & 0.74 & 0.66 & 0.56 & 0.70 & 0.72 & 0.68 & 0.73 & 0.86 & 0.71 & 0.61 & 0.78 & 0.75 & 0.55 & 0.69 & 1.00 & 0.62 & \\
\hline
\end{tabular}

Source: author's own calculation.

In the province of Silesia, one of the most polluted regions in Poland, there are 17 measuring stations. In provinces where the level of pollution is low, the number of measuring stations is smaller. In order to identify the geographical location of the main sources of environmental pollution, 
the measuring stations should be located closer in those places where the pollution is high.

What is more, the analysed methodology comes from a self-similarity or a spatial statistical self-affinity test. When analysing a region, e.g. Silesia, we can identify large agglomerations with the highest level of pollution. When considering part of a region, a segment on a flat surface, the statistical parameters of the whole region are the same as for the sub-region (statistical self-similarity). In this case, many details become clearly visible and the analysis exposes the sources of $\mathrm{SO}_{2}$ pollution more precisely.

\section{Conclusion}

Using methods deriving from the theory of stochastic processes to model the processes that take place in the surrounding world in a spatial perspective is a very useful tool as far as analyses are concerned. Connecting the methods of time series analysis and elements of spatial modelling is useful in view of the possibility to use methodology to model and analyse variability and correlation in space.

Currently, the use of stochastic process methods to model the structure and processes taking place in the surrounding world is a widely applied tool in theoretical and experimental studies, also in economics. Stochastic analysis allows us to determine the level of irregularity of the surface in a quantitative way and enables us to measure the expansion intensity of spatial phenomena. Connecting selected techniques of time series analysis and elements of spatial modelling with geometric methods is useful considering the possibility of using methodology in economic modelling and in analysis of the variability and intensity of spreading in time and space.

\section{Bibliography}

Ayache, A. and Lévy Véhel, J. (1999) "Generalized Multifractional Brownian Motion: Definition and Preliminary Results" in M. Dekking, J. Lévy Véhel, E. Lutton and C. Tricot (eds) Fractals: Theory and Applications in Engineering. New York: Springer-Verlag.

Ayache, A. and Taqqu, M. S. (2004) "Multifractional Processes with Random Exponent". Stochastic Processes and their Applications 111 (1): 119-56.

Barrière, O. (2007) Synthèse et estimation de mouvements browniens multifractionnaires et autres processus à régularité prescrite. Définition du processus autorégulé multifractionnaire et applications. $\mathrm{PhD}$ thesis, IRCCyN. 
Daoudi, K., Lévy Véhel, J. and Meyer, Y. (1998) "Construction of Continuous Functions with Prescribed Local Regularity". Constructive Approximation 14 (03): 349-85, https://doi.org/10.1007/s003659900078.

Echelard, A., Lévy Véhel, J. and Barrière, O. (2010) "Terrain Modelling with Multifractional Brownian Motion and Self-regulating Processes". Lecture Notes in Computer Science, p. 342-51, https://doi.org/10.1007/978-3-642-15910-7_39.

Falconer, K. J. and Lévy-Véhel, J. (2008) "Multifractional Multistable and Other Processes with Prescribed Local Form”. Journal of Theoretical Probability 22 (2): 375401, https://doi.org/10.1007/s10959-008-0147-9.

Hagerstrand, T. (1952) "The Propagation and Innovation Waves". Lund Studies in Geography 4. Lund: Gleerup.

Krugman, P. R. (1991) Geography and Trade. Cambridge, Massachusetts: The MIT Press.

Lévy Véhel, J. and Mendivil, F. (2011) "Multifractal and Higher-dimensional Zeta Functions". Nonlinearity 24 (1): 259-76, https://doi.org/10.1088/0951-7715/24/1/013.

Mastalerz-Kodzis, A. (2003) Modelowanie procesów na rynku kapitałowym za pomoca multifraktali [Modelling processes on the capital market with multifractals]. Prace Naukowe. Katowice: Akademia Ekonomiczna im. Karola Adamieckiego w Katowicach.

Mastalerz-Kodzis, A. (2016a) "Risk Analysis of Foreign Currency Bank Loans Offered on the Polish Capital Market" in Miroslav Čulík (ed.) Managing and Modelling of Financial Risks. VŚB-Technická Univerzita Ostrava.

Mastalerz-Kodzis, A. (2016b) "Algorytm modelowania danych przestrzennych o zadanej lokalnej regularności" [Spatial data modelling algorithm with a given local regularity]. Metody $i$ modele analiz ilościowych w ekonomii $i$ zarzadzaniu. Katowice: Wydawnictwo Uniwersytetu Ekonomicznego w Katowicach.

Mastalerz-Kodzis, A., Pośpiech, E. (2017) Application of Hölder Function to Expansion Intensity of Spatial Phenomena Analysis. Folia Oeconomica Lodziensis (in print).

Paelinck, J. H. P. and Klaassen, L. H. (1983) Ekonometria przestrzenna [Spatial econometrics]. Warsaw: PWN.

Peltier, R. F. and Lévy Véhel, J. (1995) "Multifractional Brownian Motion: Definition and Preliminary Results". Rapport de Recherche No. 2645. INRIA Recquencourt.

Suchecki, B. (2010) Ekonometria przestrzenna [Spatial econometrics]. Warsaw: C.H. Beck.

\section{Abstract}

\section{Zastosowanie multiułamkowego procesu ruchu Browna w analizach przestrzennych}

W artykule połączono metodykę stosowaną dla szeregów czasowych z elementami ekonometrii przestrzennej. Celem było zaprezentowanie zmodyfikowanej metody modelowania przestrzennego za pomocą wybranych procesów stochastycznych, a także aplikacja omawianej metody w naukach ekonomicznych oraz innych dziedzinach nauk. Hipotezę badawczą sformułowano w następujący sposób: uogólnienie na przypadek wielowymiarowy multiułamkowego procesu ruchu Browna jest użytecznym narzędziem w procesie modelowania ekonometrycznego, a także w analizie zmienności i korelacji 
w przestrzeni. W artykule zastosowano multiułamkowy proces ruchu Browna do badania stopnia oraz zmienności zanieczyszczenia środowiska. W części teoretycznej przybliżono pojęcia związane z omawianą klasą procesów stochastycznych, natomiast w części empirycznej omówiono wybrane zastosowania omawianych metod.

Słowa kluczowe: proces stochastyczny, funkcja Höldera, modelowanie przestrzenne, analiza zmienności. 